\title{
収差補正走查型透過電子顕微鏡による $\mathrm{Al}-\mathrm{Rh}-\mathrm{Cu}$ 二次元準結晶の $\mathrm{Rh}, \mathrm{Cu}$ 原子配列
}

東北大学 平 賀 贒二

日本電子株式会社 安 原 聡

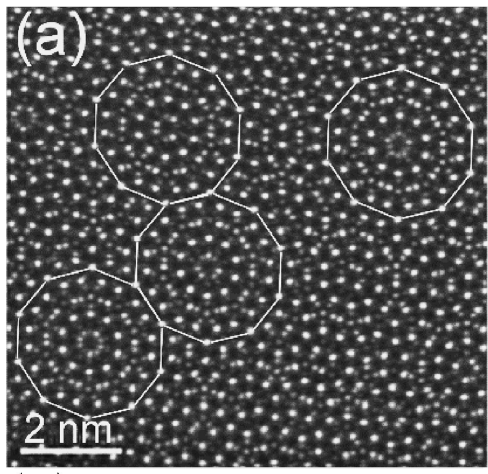

(d)

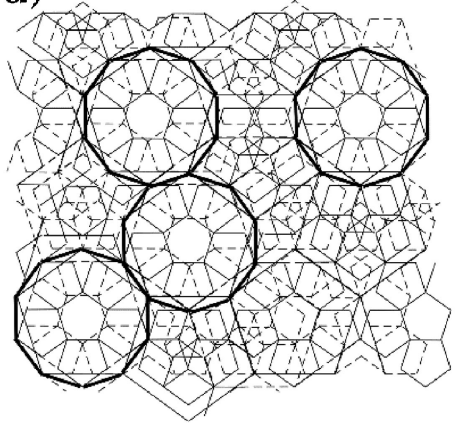

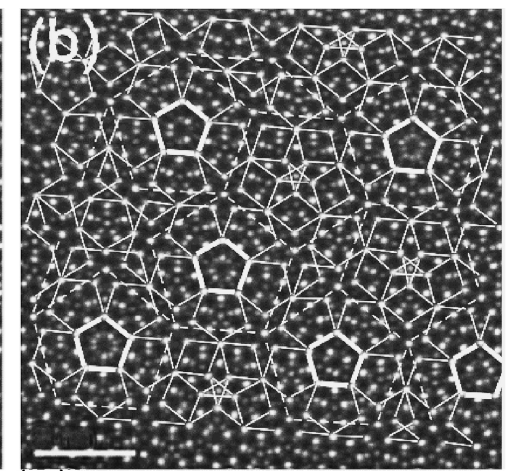

(e)

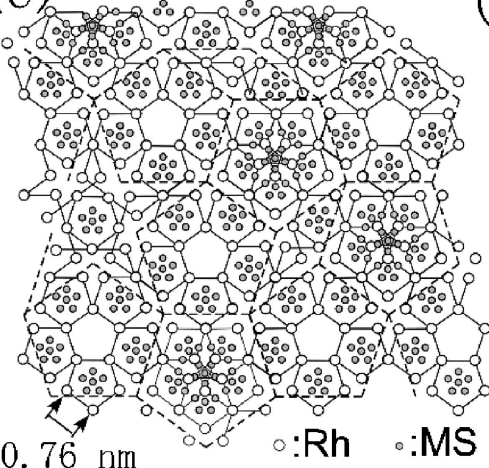

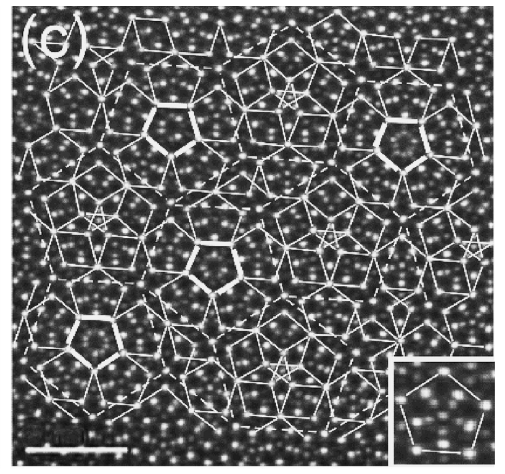

(f)

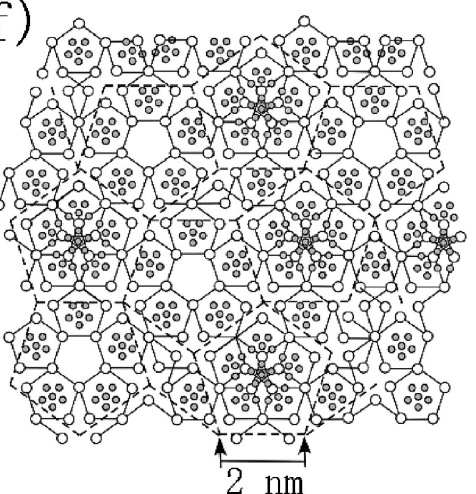

Fig. 1 Al-Rh-Cu 二次元準結晶の HAADF-STEM 像 (a), (b)，(c) とそそれから得られた A 面 (e) と B 面 (f)の Rh 原子とMSの配列.（d)は(e)と(f)の準格子の投影.

収差補正走査型透過電子顕微鏡 $(\mathrm{STEM})$ を用いて 撮られた， $\mathrm{Al}-\mathrm{Rh}-\mathrm{Cu}$ 二次元準結晶の周期軸入射の High-angle annular detector dark-field (HAADF) 観 察像から $\mathrm{Rh}$ 原子と $\mathrm{Al}, \mathrm{Cu}$ 原子の mixed site $(\mathrm{MS})$ の 配列を明らかにしたものである(1).Fig. 1 の HAADF-STEM 像内の強いコントラストの輝点を結 んでできる 2 種類の $0.76 \mathrm{~nm}$ ボンド長の準周期格子 (b)，(c) は，周期軸方向に積層した A 面 (e) と B 面 $(\mathrm{f})$ の Rh 原子の準周期格子に対応する.（b)の五角形準 周期格子の下向きの五角形タイルおよび (c)の上向き 五角形タイル内に，（c）の右下に挿入した拡大写真に 示したように，輝点の 2 重 5 角形配列が存在し，そ の内側の比較的弱い輝点が MS に対応する. (e) と (f)
の $0.76 \mathrm{~nm}$ ボンド長の準周期格子内の星型 5 角形の 中心を結ぶと， $\tau^{2}-$ inflated $(2 \mathrm{~nm}$ ボンド長の) 準周期 格子 $(\mathrm{A}$ 面と $\mathrm{B}$ 面では異なる)ができる. A 面と B 面 の $0.76 \mathrm{~nm}$ ボンド長の準周期格子の投影図 $(\mathrm{d})$ に, 10 回回転対称の $3.2 \mathrm{~nm}$ 直径の正 10 角形クラスターが現 れている.

\section{文献}

(1) K. Hiraga, A. Yasuhara, K. Yamamoto and K. Yubuta: Philos. Mag., 95(2015), 1524-1535.

(2016年 7 月 22 日受理) [doi:10.2320/materia.55.607]

Arrangement of $\mathrm{Rh}$ and $\mathrm{Cu}$ Atoms in an $\mathrm{Al}-\mathrm{Rh}-\mathrm{Cu}$ Decagonal Quasicrystal by $\mathrm{Cs}-$ corrected STEM; Kenji Hiraga* and Akira Yasuhara** (*Tohoku University, Sendai. **EM Application Group, JEOL Ltd., Akishima)

Keywords: Al-Rh-Cu, decagonal quasicrystal, Cs-corrected STEM, scanning transmission electron microscopy

TEM specimen preparation: dispersing crushed materials on a holey carbon film

TEM utilized: JEM-ARM200F $(200 \mathrm{kV})$ 